Journal of Global Strategic Management | V. 9 | N. 1 | 2015-June | isma.info | 65-74 | DOI: 10.20460/JGSM.2015915629

\title{
STRATEGIC MANAGEMENT APPROACH IN THE METROPOLITAN MUNICIPALITIES IN TURKEY: AN ANALYSIS ON THE STATEMENTS OF MISSION, VISION AND CORE VALUES
}

\author{
*Adnan KALKAN \\ *Ozlem Cetinkaya BOZKURT \\ *Sezai OZTOP \\ *Melike Siseci CESMELI \\ *Mehmet Akif Ersoy University, Turkey
}

\begin{abstract}
In this paper, it has been aimed that the strategic management approach in the metropolitan municipalities in Turkey are evaluated by examining the vision, mission and core value statements on their strategic plans which have been prepared and put into effect for the period from 2015 to 2019. Firstly, strategic management is introduced, and legislative / regulatory developments related to the strategic management approach in Turkish Public Administration are summarized in the literature review. In the methodology section, the vision, mission and core value statements specified in the strategic plans of 26 metropolitan municipalities are examined by means of 12 criteria, consisting of 4 criteria for each statement type, which have been determined according to the legislations and regulations related to strategic planning in Turkey in line with the literature. In addition, the most common values in the core value statements are determined with their frequencies by means of content analysis method. As a conclusion, it has been determined that the metropolitan municipalities in Turkey have substantially met the requirements in relation to the vision, mission and core value statements although there are some missing points such as activity area, purpose of existence, services provided, future ideals and inspirations especially in mission and vision statements. Moreover, it is observed that the metropolitan municipalities have some common values such as transparency, participative management, economical use of resources, trust, justice and equality, accountability, environment-friendly practices, commitment to history and culture, and availability for change and development.
\end{abstract}

Keywords: Core Values; Metropolitan Municipality; Mission; Public Administration; Strategic Management; Vision.

\section{INTRODUCTION}

Both public and private organizations have started to incline to benefit from the strategic management approach in the last years of $20^{\text {th }}$ century in which a fast transformation went through, in order to continue their activities to meet the changing demands of customers or citizens. First of all, strategic thinking includes the prediction of possible opportunities and risks related to the activities of an organization for the future, and the determination of mission, vision and core values in relation to these predictions, and also requires continuous communication with stakeholders within this process. Accordingly, it is expected that the strategic management approach contributes to strategic thinking, determination of priorities, application of the activities focused on the projections effectively and also control over the implementation and results of the activities specified.

\section{LITERATURE REVIEW}

\section{Strategic Management}

Emerging of strategic concepts in business management occurs after the World War II. The process which is started as planning continued in different concepts such as budget and financial control, long-term planning, commercial strategic planning, common strategic planning and strategic management (Cevik, 2010: 138-139; 


\section{Journal of Global Strategic Management | V. 9 | N. 1 | 2015-June | isma.info | 65-74 | DOI: 10.20460/JGSM.2015915629}

Parlak and Sobaci, 2010: 300). At this point, significance of "planning" approach that includes planning everything has weakened in time (Al, 2007: 6) and it has been replaced by strategic management approach that includes also strategic planning.

Strategic management is one of the techniques among the contemporary management approaches which is adopted by both public and private sectors. Strategic management is the integration of decisions and activities to affect and determine the long-term success of organizations (Efil, 2010:269). Accordingly, the decisions which are made in strategic management are for the organizational future. Characteristics of strategic management enable an organization to determine its mission and vision for the success in the future and take advantage of a planning process especially for top-management and evaluate interior and exterior environments and determine its strong and weak points and plan, organize, coordinate, implement and control the activities for its success in the future, and to realize a team work and solve the problems effectively and finally determine applicable strategies. Techniques used within this management approach are SWOT Analysis, Portfolio Analysis, Q-Sort Analysis, Scenario Analysis, Search Conference, Delphi Technique, Nominal Group, Multi-voting, Open Group, Quality Chambers, Cost-Benefit Analysis and Risk Analysis (Aktan, 2008: 6-9). Main purpose of these techniques is to enable an organization to make its best decision in the quickest way and in a participative management approach. Therefore, although strategic management is a responsibility of top-management, it enables the stakeholders to participate in decisionmaking process.

Strategic management and strategic planning concepts are used in the same meaning especially in the implementation. That is why strategic planning includes planning for both application and control phases. On the other hand, some researchers (e.g; Liou, 2000: 462; Toft, 2000: 4; Eadie, 2000: 124; Wilson, 1998: 507) approach strategic management as a developed form of strategic planning. Actually, strategic planning is the formulation stage of strategic management in the first phase. Strategic planning may be defined as a disciplined work to determine what an organization is and what and why it does, and also to make main decisions and carry out activities as a guide (Bryson, 2004: 6). Strategic management is described also as a science and art to formulate, implement, control and evaluate the decisions which are made to accomplish organizational aims (David, 2001: 5). As it is inferred from the definition, strategic management includes both determination of strategies toward organizational aims and control of their implementation and the success of the process.

In other words, strategic planning means determination of what should be done today in order to have tomorrow (Tumer, 1993: 90). It might be defined also as the disciplined works to determine important decisions to direct organizational and managerial activities within specific conditions (Cevik, 2010: 144). Therefore, strategic planning is a result-oriented method like a road map which indicates the distance between the present and future positions of an organization and includes directions and activities to be accomplished and check points.

\section{Statements of Vision, Mission and Core Values}

\section{Mission}

The natural role and importance of mission statements have been examined for over three decades in the management literature (Pearce, 1982; Pearce \& David, 1987; Powers, 2012). A mission statement broadly charts the future direction of an organization (Kemp \& Dwyer, 2003). A mission statement establishes the values, beliefs, and guidelines for the way the organization conducts its business and determines its relationships with its stakeholders (employees, customers, shareholders, suppliers, government, and the community) (Ackoff, 1987). A well-designed mission statement is essential for formulating, implementing, and evaluating business strategy (David, 2001). The role of the mission statement in the strategic management of business firms has not been sufficiently highlighted in the research literature. Development of an organizational mission is an essential part of strategic planning and strategic management (David, 2001).

There is no consensus about the contents of the mission statements. For example, Bart (2007) asserts that a mission statement should include aims, values, specific services provided, customer satisfaction, position demanded, general business level, goals, competition strategy and the definition of the technology used. Generally, it is stipulated explicitly in the literature related to strategy, and theories that the mission 
statements should be prepared with respect to unique organizational features (Bart, 2001; Bart \& Baetz, 1998; Bart \& Tabone, 1999; Bart et al, 2001; David, 1989; Bartkus et al, 2000).

Mission is a purpose of existence of an organization and constitutes a framework how to accomplish strategic aims. In an organization with a defined mission, employees comprehend better how and what for they will work. It enables them to be more successful at what they do (Dogan, 2000: 188). Mission statements include what sector (product or service) organizations make business in, and their main products and services, consumer and market requirements and also technological requirements (Eren, 2010: 21).

A mission statement includes some components including specific features of an organization such as its philosophy, social matters, image, quality, methods and standards, activity area, primary competitive superiorities, key processes and technologies which distinguish it from other organizations, and also statements toward its stakeholders. In a mission statement, there should be a purpose of existence of an organization, its future position aimed, and targets to be accomplished and division of labor, and job descriptions (Aktan, 1999: 27). There are many benefits to have a mission determined. First of them is to become used to discussing about useful ones in the organization. Other is clarification of organizational and social aims. Thus, it provides an effective leadership. Determination of aims prevents disagreements and conflicts within the organization and enables problems to be solved quickly and easily. Therefore, leaders control works better.

Mission statement should be short, clear, spectacular and descriptive rather than including service provision processes. Also it should define tasks and powers of an organization, and include persons and institutions that are provided products and/or services (stakeholders), and define services and/or products of the organization (DPT, 2006: 20).

\section{Vision}

Vision is a description or design of the future position of an organization according to its imagination. Vision, as a first step of strategic planning, means a form of future position imagined by considering the products and services of the organization. There are various definitions for vision. According to Lissack and Roos (2001: 55), it is a course of an organization for the long-term success. Gill (2003: 312) states vision as a future point demanded to direct various efforts. Vision is also an indication of managers' rating of inspiration from other people's views and contributions, and also inclination of the managers toward improvement, originality and creativity (Eren, 2010: 19).

Vision enables employees to focus the same target. Vision provides a guidance for employees and develops definitions and descriptive principles about how to work while trying to accomplish aims. Vision includes an assertive and imaginary statement of a position in the future which an organization wants to reach. The statement should encourage employees and decision-makers to improve their efforts and also be realistic. Vision statement constitutes the roof of planning process together with mission statement. A vision statement should be short and easy to remember; inspirational and assertive, and defines future successes and ideals. Also, it should be charming for all stakeholders (DPT, 2006: 21).

\section{Core Values}

Core values mean organizational principles and values, organizational understanding and behavioral rules, and they are mostly confused with strategy concept, and named also as policies. Principles create limits for aims and means. These limits are helpful for managers, and enable them to make quick and easy decisions. These limits describes the rules to be applied when specific conditions are encountered, and confine discretions (Guner, 2005: 61).

Determination of principles of an organization is important for strategic management. Because these principles constitute the foundation of the values and beliefs behind vision and mission of the organization. Principles prevent repeating decision-making process under similar conditions, and provides objectivity and consistency. Thus, the behaviors of managers can be estimated and the transfer of authority is provided. Therefore, managers can use initiative and institutionalization is increased. Core value statements includes three main areas: people (employees and other people), processes (management, decision-making and service provision) and performance (expectations toward the service and product quality from organization) (DPT, 2006:23). 


\section{Development of Strategic Management Approach in Turkish Public Administration}

Inclusion of strategic management approach into Turkish Public Administration took place with the Public Financial Management and Control Act 5018 on 24 December 2003. Strategic plan, as a reflection of strategic management approach, is defined in the third article of the act as a plan which includes short and long term aims, main principles and policies, targets and priorities, performance criteria of the public organizations, the methods and resource distribution to reach these requirements. Article 9 of the act imposes some responsibilities on public organizations in relation to strategic planning such as determination of mission and vision statements, strategic aims and measurable targets, carry out performance evaluations in the line of predetermined aims and indications, preparation of strategic plan, and attribution of budgets on strategic plans, annual aims and performance indications in order to provide public services in preferable quality and level. In addition, the act has authorized the State Planning Agency (DPT) to determine the methods and principles of strategic planning process for public organizations.

A Strategic Planning Guide has been prepared by DPT in 2003 in order to help and direct the strategic planning process of the public organizations. This guide presents a general framework for strategic planning process and the scope and content of the strategic plans. The guide includes information about main concepts and approaches related to strategic planning such as mission, vision and core value statements. The guide has specified four main purposes of strategic planning as (i) to provide financial discipline in macro-level, (ii) to distribute the resources according to strategic priorities, (iii) to control the efficient use of resources and (iv) to develop the accountability (DPT, 2003: 2).

Strategic planning approach is included also in the Metropolitan Municipality Act, 5216 in 2004 and the Municipality Act, 5393 in 2005 and the Provincial Special Administration Act, 5302 in 2005. Later in $26^{\text {th }}$ May 2006, a regulation has been issued in relation to implementation of strategic planning in public organizations. Thus, a schedule has been determined for public organizations to implement strategic planning, and it has required public organizations to prepare their first strategic plans until 31 January 2009. Additionally, the regulation requires public organizations to comply with the requirements specified in the guide and the regulation.

\section{Implementation of Strategic Planning in the Municipalities of Turkey}

In comparison with other local government agencies, municipalities have come to the forefront in terms of public-service provision due to some causes such as the increase in urban population, constantly-increasing and changing social demands and emerging of subsidiarity. Accordingly, municipalities have inclined to benefit from new management approaches (Azakli, 2002: 418; Yuksel, 2002: 36; Oztop, 2007: 107). One of the management approaches applied is strategic planning. Strategic planning is considered important in terms of determination of public-service priorities and resources, and effective use of resources, and minimization of costs for a specific period (Yuksel, 2002: 32). This thought has been reflected on the recent legislations and regulations. The Metropolitan Municipality Act, 5216 includes the preparation of strategic plan as one of the tasks of metropolitan municipalities. The act also requires mayors to manage municipalities according to strategic plans. The Municipality Act, 5393 requires strategic plan to be prepared and followed by mayors after being discussed and approved in the municipal council. The act orders municipalities to determine and perform their activities in line with the strategic plans. Article 41 of the Act requires that the municipalities having more than 50.000 population prepare strategic plans. Today, the municipalities in Turkey have applied their third period strategic plans since they started to prepare it in 2006.

\section{METHODOLOGY}

\section{Research Goal}

In this paper, it is aimed that the mission, vision and core value statements specified in the Strategic Plans of the Metropolitan Municipalities in Turkey are examined. The mission, vision and core value statements of metropolitan municipalities are expected to indicate the implementation level of strategic management by them. 


\section{Sample and Data Collection}

The strategic plans which include the mission, vision and core value statements of the metropolitan municipalities in Turkey constitute the population of this research. Although there are 30 metropolitan municipalities in Turkey, only 26 strategic plans have been obtained since 4 metropolitan municipalities have not prepared or published their strategic plans. Therefore, scope of this research is limited to 26 strategic plans. The data used in this research have been obtained from the strategic plans issued in the web sites of 26 municipalities. Names of the Metropolitan Municipalities and periods of the strategic plans are listed in Table1.

The mission, vision and core value statements have been examined with the content analysis. Strategic plans of the metropolitan municipalities have been examined in terms of three criteria (mission, vision, core values) and the priorities of municipalities have been determined. The notions in the statements have been selected in a way to enable various inferences and enlighten the research; inconsistent words have been avoided not to break integrity of the research. Content analysis has been used as qualitative research method to analyze and determine frequencies of the core values. The purpose of using the content analysis is to reach the concepts and relations in order to explain data collected (Demirci and Koseli, 2009: 339). Content analysis is a collection and analysis technique for text content (Neuman, 2006: 466). In the beginning, research questions have been determined. In the second stage, categorical division process has been carried out. Some headings have been determined to create categorical groups. Later, coding process has been carried out. The texts in the sample have been read and the notions have been collected according to the headings determined. Coding process has been accomplished by using MS Office Excel program. Repeating words in the core value statements have been collected. Frequency analysis technique which is mostly-used in the content analysis has been used. Findings obtained from the analysis have been explicated. The four questions replied in this research as follows:

Question 1: Do the mission statements of metropolitan municipalities comply with the criteria specified in the legislations and regulations?

Question 2: Do the vision statements of metropolitan municipalities comply with the criteria specified in the legislations and regulations?

Question 3: Do the core value statements of metropolitan municipalities comply with the criteria specified in the legislations and regulations?

Question 4: Is there any similarities among the notions in the core value statements of metropolitan municipalities?

\section{Table 1. List of the Strategic Plans}

\begin{tabular}{|l|l|l|l|l|l|}
\hline No & Metropolitan Municipality & Strategic Plan Period & No & Metropolitan Municipality & Strategic Plan Period \\
\hline $\mathbf{1}$ & Adana & $2015-2019$ & 16 & Kayseri & $2015-2019$ \\
\hline $\mathbf{2}$ & Ankara & $2015-2019$ & 17 & Kocaeli & $2015-2019$ \\
\hline $\mathbf{3}$ & Antalya & $2015-2019$ & 18 & Konya & $2015-2019$ \\
\hline $\mathbf{4}$ & Aydin & $2015-2019$ & 19 & Malatya & $2015-2019$ \\
\hline $\mathbf{5}$ & Balikesir & $2015-2019$ & 20 & Manisa & $2015-2019$ \\
\hline $\mathbf{6}$ & Bursa & $2015-2019$ & 21 & Mardin & Non Available \\
\hline $\mathbf{7}$ & Denizli & $2015-2019$ & 22 & Mersin & $2015-2019$ \\
\hline $\mathbf{8}$ & Diyarbakir & Non Available & 23 & Mugla & $2015-2019$ \\
\hline $\mathbf{9}$ & Erzurum & Non Available & 24 & Ordu & $2015-2019$ \\
\hline $\mathbf{1 0}$ & Eskisehir & $2015-2019$ & 25 & Sakarya & $2015-2019$ \\
\hline $\mathbf{1 1}$ & Gaziantep & $2015-2019$ & 26 & Samsun & $2015-2019$ \\
\hline $\mathbf{1 2}$ & Hatay & $2012-2016$ & 27 & Sanliurfa & $2012-2016$ \\
\hline $\mathbf{1 3}$ & Istanbul & $2015-2019$ & 28 & Tekirdag & $2015-2019$ \\
\hline $\mathbf{1 4}$ & Izmir & $2015-2019$ & 29 & Trabzon & $2015-2019$ \\
\hline $\mathbf{1 5}$ & Kahramanmaras & $2015-2019$ & 30 & Van & Non Available \\
\hline
\end{tabular}




\section{Analyses and Results}

In this research, total 12 criteria have been determined with 4 criteria for each statement with respect to the regulation and the guide in relation to strategic planning in public organizations. This criteria have been transformed into questions to answer with Yes/No. These questions and answers (Yes $=+$ ) are indicated in Table 2.

\section{Table 2. Analysis on the Statements of Vision, Mission and Core Values}

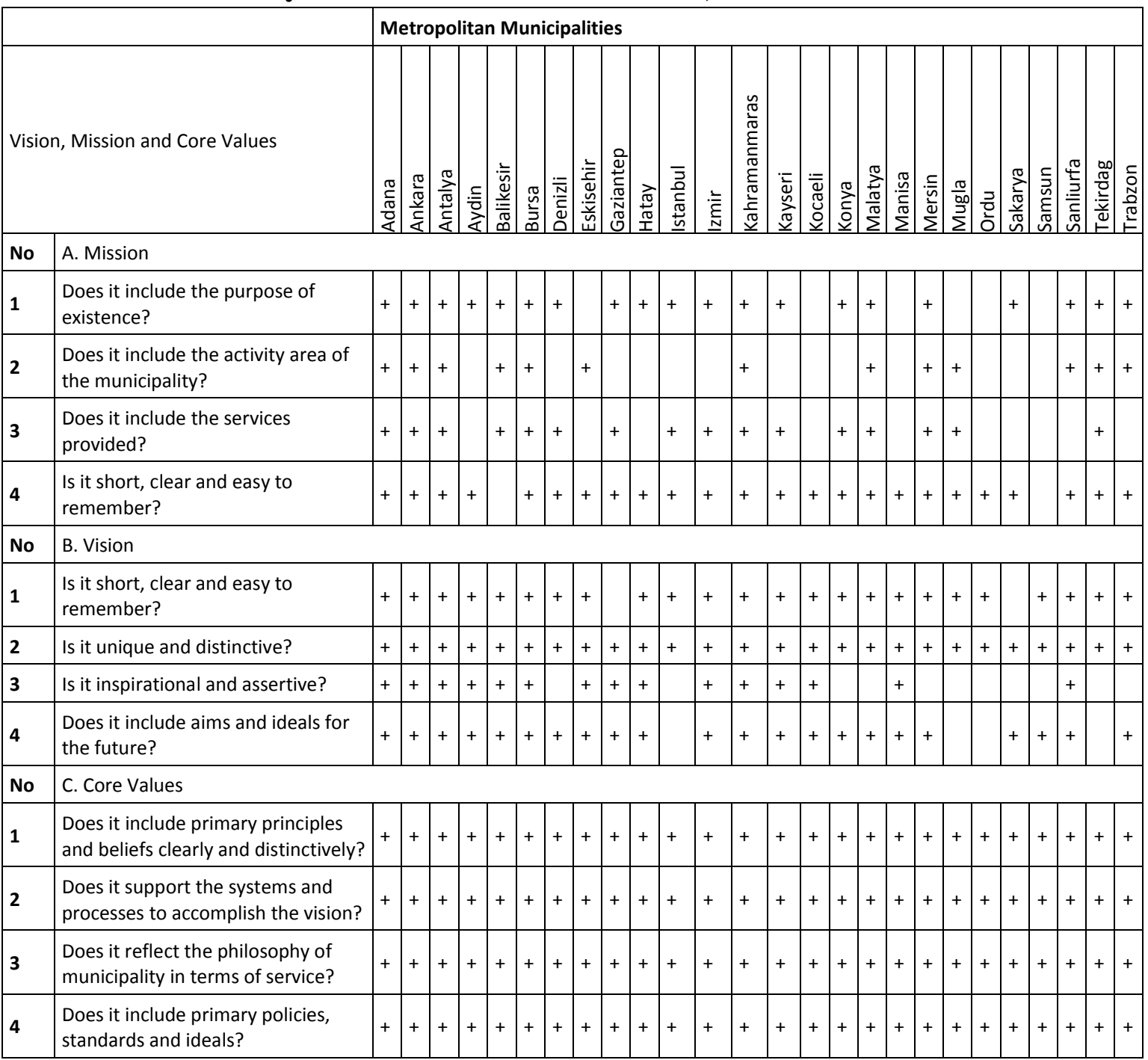

In Table 2, there are three sections consisting of 4 questions for each statement type (A. Vision; B. Mission and C. Core Values). According to the table, it appears in Section A that most of the mission statements are short, clear and easy to remember, but half of them does not include activity area. Also it is observed that some of the mission statements does not include the purpose of existence and the services provided.

In terms of vision statements (Section B), it appears that although all of the vision statements are unique and distinctive and most of them are short, clear and easy to remember, some of them are not inspirational and assertive, and do not include aims and ideals for the future.

In section C, it appears that all the core value statements include primary principles and beliefs and support the systems and processes to accomplish their visions and reflect service philosophies of the municipalities and include primary policies, standards and ideals. The core value statements are the best section at which the municipalities are good. 
Journal of Global Strategic Management | V. 9 | N. 1 | 2015-June | isma.info | 65-74 | DOI: 10.20460/JGSM.2015915629

In Table 3, there are 26 values in columns which have been found as the most frequent ones in the value statements examined. Core value statements have been examined and the frequency numbers of the values in the columns are indicated for each metropolitan municipality in the table. According to the Table 3, it appears that all the municipalities have specified transparency as one of the core values. Other common values in terms of their frequencies are participative management (which has been stated by 25 municipalities), economic use of resources (21 municipalities), trust (20), justice and equality (20), accountability (19), environment-friendly municipality (19), commitment to history and culture (16), availability for change and development (14), citizen-oriented municipality (13), citizen satisfaction (13), service quality (12), social municipality (11), science and technology (10), respect and tolerance to human (10), objectivity (9), total quality management (9), honesty (7), fast in service provision (7), respect to law (7), sustainable development (7), vocational and social development (7), team work (7), respect to ethics (6), public interest (6) and loyalty (6).

\section{Table 3. Frequencies of the Core Values}

\begin{tabular}{|c|c|c|c|c|c|c|c|c|c|c|c|c|c|c|c|c|c|c|c|c|c|c|c|c|c|c|}
\hline Municipalities & 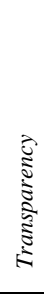 & 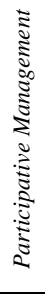 & 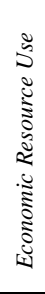 & $\underset{\mathrm{E}}{\breve{\mathrm{z}}}$ & 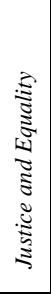 & 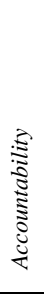 & 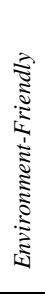 & 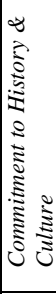 & 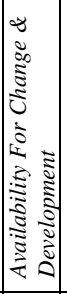 & 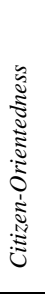 & 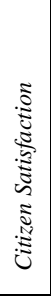 & 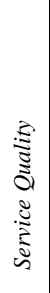 & 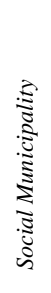 & 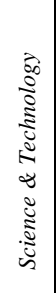 & 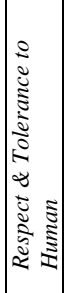 & 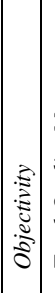 & 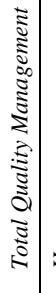 & 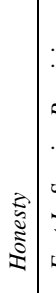 & 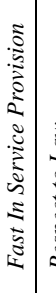 & 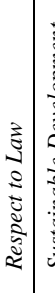 & 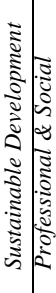 & & 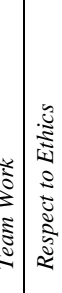 & 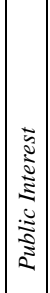 & 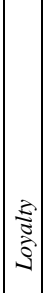 & 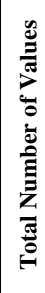 \\
\hline Adana & + & + & + & & + & & & + & & + & & & + & & & & . & + & & & & & & + & & 9 \\
\hline Ankara & + & & + & & & + & + & + & & & & & & & + & & + & & & + & & + & + & & & 10 \\
\hline Antalya & + & + & + & + & + & + & + & + & + & + & + & + & & & & & & & $+\mid$ & + & & & + & & & 15 \\
\hline Aydin & + & + & + & + & & + & + & & + & + & + & + & & & + & + & & & + & & & ++ & + & + & & 16 \\
\hline Balikesir & + & + & + & + & + & + & + & + & & + & & & & + & & & 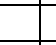 & & & \begin{tabular}{l|l}
+ & - \\
\end{tabular} & \begin{tabular}{l|l}
+ & - \\
\end{tabular} & + & + & & & 14 \\
\hline Bursa & + & + & + & + & & & + & & + & & & & + & & & + & + & & & & & & & & & 9 \\
\hline Denizli & + & + & + & + & + & + & + & + & + & + & & & + & + & + & & + & & & 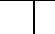 & & + & & & + & 16 \\
\hline \begin{tabular}{|l} 
Eskisehir \\
\end{tabular} & + & + & & + & & + & + & & + & & & + & & & + & + & & + & & $+\quad+$ & + & & + & & + & 14 \\
\hline Gaziantep & + & + & & + & + & + & & & & + & + & & & & & + & & & & & + & & & & & 9 \\
\hline Hatay & + & + & + & + & + & + & + & + & & + & & + & + & + & & & & & + & & & & & & & 13 \\
\hline Istanbul & + & + & + & + & + & & & & & & & + & & & & & + & & & & & & & & & 7 \\
\hline \begin{tabular}{|l|} 
Izmir \\
\end{tabular} & + & + & + & + & + & + & + & + & + & & + & & + & + & & + & + & + & & \begin{tabular}{l|l}
+ & - \\
\end{tabular} & + & & \begin{tabular}{l|l}
++ & + \\
\end{tabular} & + & & 20 \\
\hline K. Maras & + & + & + & & + & + & + & + & + & & + & + & + & + & + & & & & + & & & & & & & 14 \\
\hline Kayseri & + & + & + & + & + & & + & + & + & + & + & + & + & & + & & & & & & & ++ & + & & & 15 \\
\hline \begin{tabular}{|l} 
Kocaeli \\
\end{tabular} & + & + & + & & & + & + & + & & + & & + & + & + & & & & & & + & & & + & & + & 13 \\
\hline \begin{tabular}{|l|} 
Konya \\
\end{tabular} & + & + & + & + & + & + & & + & & + & & & & + & & & + & + & & & \begin{tabular}{l|l}
+ & - \\
\end{tabular} & \begin{tabular}{l|l}
+ & + \\
\end{tabular} & \begin{tabular}{l|l}
+ & + \\
\end{tabular} & & + & 16 \\
\hline \begin{tabular}{|l|} 
Malatya \\
\end{tabular} & + & + & & + & + & & + & + & + & & + & & + & & & & & & & & & & + & & + & 11 \\
\hline Manisa & + & + & + & + & + & + & & + & + & + & + & + & & & + & & + & & & & & & & & + & 14 \\
\hline Mersin & + & + & + & + & + & + & & + & & & + & & & & & & + & & & & + & & + & + & & 12 \\
\hline \begin{tabular}{|l|} 
Mugla \\
\end{tabular} & + & + & + & + & + & + & & & & & & + & & & & + & + & \begin{tabular}{l|l}
+ & \\
\end{tabular} & + & & & & & & & 11 \\
\hline Ordu & + & + & + & & + & + & + & & & & & & & + & + & & & & & & & + & & & & 9 \\
\hline Sakarya & + & + & + & + & + & + & + & & + & & + & + & & & + & + & & & & + & & & & & & 13 \\
\hline Samsun & + & + & & + & + & + & + & & + & & + & & & + & + & + & & + & + & & & & & & & 13 \\
\hline \begin{tabular}{|l|} 
Sanliurfa \\
\end{tabular} & + & + & & & + & & + & + & + & + & & & & & & & & \begin{tabular}{l|l}
+ & \\
\end{tabular} & + & & & & & & & 9 \\
\hline Tekirdag & + & + & + & + & + & & + & + & + & + & + & + & + & & & & & & & & & & & + & & 13 \\
\hline \begin{tabular}{|l|} 
Trabzon \\
\end{tabular} & + & + & + & + & & + & + & & & & + & & + & + & & + & & & & & + & & & + & & 12 \\
\hline $\mathrm{f}$ & 26 & 25 & 21 & 20 & 20 & 19 & 19 & 16 & 14 & 13 & 13 & 12 & 11 & 10 & 10 & 9 & 9 & \begin{tabular}{l|l}
7 & \\
\end{tabular} & \begin{tabular}{l|l}
7 & 7 \\
\end{tabular} & \begin{tabular}{l|l}
7 & 7 \\
\end{tabular} & \begin{tabular}{l|l}
7 & 7 \\
\end{tabular} & \begin{tabular}{l|l}
7 & 7 \\
\end{tabular} & \begin{tabular}{l|l}
7 & 6 \\
\end{tabular} & 6 & 6 & \\
\hline
\end{tabular}

\section{CONCLUSION}

Strategic planning has been considered as one of the tools of strategic management in Turkish Public Administration since 2003. Turkish Municipalities have used strategic planning since it was imposed by an Act in 2006. Today they have applied third-period strategic plans since that time.

In this paper, the statements of mission, vision and core values in the strategic plans of 26 metropolitan municipalities in Turkey have been examined. According to results, mission, vision and core values comply with the criteria specified in the legislations and regulations, and there are some similarities among the notions in the core value statements of the metropolitan municipalities. 


\section{Journal of Global Strategic Management | V. 9 | N. 1 | 2015-June | isma.info | 65-74 | DOI: 10.20460/JGSM.2015915629}

According to the findings, although the section of core value statements is the best section at which the metropolitan municipalities are all good, the sections of mission and vision statements are not so good. It requires that the mission statements should include activity area of municipality, purpose of existence and the services provided. Vision statements should be inspirational and assertive, and include aims and ideas of the municipality for the future. It is observed that the most frequent values in the core value statements is transparency. Other most common values which have been stated by more than half of the municipalities are participative management, economic use of resources, trust, justice and equality, accountability, environment-friendly municipality, commitment to history and culture, and availability for change and development.

As a conclusion, it is observed that the statements of mission, vision and core values specified by the municipalities in the strategic plans have substantially met the criteria in the legislation and regulations. However, there are still some points which need to be developed. Activity area, purpose of existence, and services provided are required to be included in the mission statements. In addition, future ideals and inspirations should be reviewed and developed in the vision statements.

This paper is important in terms of determination of the faults and missing points in the mission, vision and core value statements of 26 metropolitan municipalities in Turkey. For subsequent studies, it is recommended to examine whether these statements are taken into account efficiently while determining strategic goals and activities of the metropolitan municipalities. 


\section{REFERENCES}

Ackoff, R. (1987). “Mission Statements”, Planning Review, 15(4), 30-31.

Adana Buyuksehir Belediyesi Stratejik Plani, 2015-2019.

Aktan, C. C. (1999). 2000’li Yillarda Yeni Yonetim Teknikleri: Stratejik Yonetim, Tugiad Yayinlari, Istanbul.

Aktan, C. C. (2008). “Stratejik Yonetim ve Stratejik Planlama”, Cimento Isveren Dergisi, Temmuz-Agustos, 4-21.

Al, H. (2007) "Kamu Mali Yonetimi ve Kontrol Kanunu ve Turk Kamu Yonetiminde Yeni Denetim Yaklasimlari”; Editorler: Eryilmaz, B.; Eken, M.; Sen, M. L. "Kamu Yonetimi Yazilari: Teoride Degisim, Yeniden Yapilanma, Sorunlar ve Tartısmalar", Nobel Yay., Ankara, s.1-23.

Ankara Buyuksehir Belediyesi Stratejik Plani, 2015-2019.

Antalya Buyuksehir Belediyesi Stratejik Plani, 2015-2019.

Aydin Buyuksehir Belediyesi Stratejik Plani, 2015-2019.

Azakli, S. (2002). "Belediyelerin Hizmet Stratejileri Belirleme Surecinde Analizci Yaklasimin Onemi”, Yerel Yonetimler Sempozyumu Bildirileri, TODAIE Yayin No: 304, Ankara, ss.413-436.

Balikesir Buyuksehir Belediyesi Stratejik Plani, 2015-2019.

Bart, C. (2001). "Measuring the Mission Effect in Human Intellectual Capital”, Journal of Intellectual Capital Res. 2(3), 320-330.

Bart, C. (2007). “A Comparative Analysis of Mission Statement Content in Secular and Faith-based Hospitals”, Journal of Intellectual Capital. 8(4), 682-694.

Bart, C. \& Bontis, N. \& Taggar, S. (2001). “A Model of Mission Statements \& Firm Performance”, Management Dec. 39(1), 19-35.

Bart, C. \& Baetz, M.J. (1998). "The Relationship Between Mission Statements and Firm Performance: An Exploratory Study”, Journal of Management Studies 36 (6), 823-853.

Bart, C. \& Tabone, J.C. (1999). "Mission Statement Content and Hospital Performance in the Canadian Notfor-profit Health-care Sector”, Health Care Management Review 24(3), 18-29.

Bartkus, B., Glassman, M. \& Mcafee, B. (2002). "Do Large European, US and Japenese Firms Use Their Web Sites to Communicate their Mission?” European Management Journal, 20(4), 423-424.

Bryson, J. M. \& Alston, F. K. (2004). Creating and Implementing Your Strategic Plan: A Workbook for Public and Nonprofit Organizations, Jossey Bass: A Wiley Imprint, Second Edition, San Francisco.

Bursa Buyuksehir Belediyesi Stratejik Plani, 2015-2019.

Cevik, H. (2010). Kamu Yonetimi: Kavramlar, Sorunlar, Tartismalar, Seckin Yayinlari, Ankara.

David, F. (1989). How Companies Define Their Mission, Long Range Planning, 22(1), 90-97.

David, F. (2001). Strategic Management Concepts (8th Ed.). Upper Saddle River, NJ: Macmillan.

Demirci, S. ve Koseli, M. (2009). "Ikincil Veri ve Icerik Analizi”, Sosyal Bilimlerde Arastirma Yontemleri, 3. Baski, Editor: Kaan BOKE, Alfa Yayinlari, Istanbul. DPT, Kamu Kuruluslari icin Stratejik Planlama Kilavuzu, Ankara.

Denizli Buyuksehir Belediyesi Stratejik Plani, 2015-2019.

Dogan, S. (2000). “Isletmelerde Vizyon ve Misyon Bildirisi Gelistirme ve Onemi”, 8. Ulusal Yonetim ve Organizasyon Kongresi Bildiriler Kitabi, Erciyes Universitesi, Nevsehir.

DPT (2006). Kamu Idareleri icin Stratejik Planlama Kilavuzu, Haziran 2006.

Efil, I. (2010). Isletmelerde Yonetim ve Organizasyon, Dora Yayinlari, Bursa Eren E. (2010). Stratejik Yonetim ve Isletme Politikasi, Beta Yayinevi, 9. Baski, Istanbul.

Eskisehir Buyuksehir Belediyesi Stratejik Plani, 2015-2019.

Gaziantep Buyuksehir Belediyesi Stratejik Plani, 2015-2019. 
Gill, R. (2003). “Change Management or Change Leadership?” Journal of Change Management, 3(4), 307318.

Guner, S. (2005). “Stratejik Yonetim Anlayisi ve Kamu Yonetimi”, Turk Idare Dergisi, Sayi: 446, s.61-70, Ankara.

Hatay Buyuksehir Belediyesi Stratejik Plani, 2012-2016.

Istanbul Buyuksehir Belediyesi Stratejik Plani, 2015-2019.

Izmir Buyuksehir Belediyesi Stratejik Plani, 2015-2019.

Kahramanmaras Buyuksehir Belediyesi Stratejik Plani, 2015-2019.

Kayseri Buyuksehir Belediyesi Stratejik Plani, 2015-2019.

Kemp, S. \& Dwyer, L. (2003). “Mission Statements of International Airlines: a Content Analysis”, Tourism Management, 24(6), 635-653.

Kocaeli Buyuksehir Belediyesi Stratejik Plani, 2015-2019.

Konya Buyuksehir Belediyesi Stratejik Plani, 2015-2019.

Lissack, M. \& Roos, J. (2001). Be Coherent, Not Visionary, Long Range Planning, 34 (1), 53-70.

Malatya Buyuksehir Belediyesi Stratejik Plani, 2015-2019.

Manisa Buyuksehir Belediyesi Stratejik Plani, 2015-2019.

Mersin Buyuksehir Belediyesi Stratejik Plani, 2015-2019.

Mugla Buyuksehir Belediyesi Stratejik Plani, 2015-2019.

Neuman, W.L. (2006). Toplumsal Arastirma Yontemleri Nitel ve Nicel Yaklasimlar, Ceviren: Sedef OZGE, Yayın Odasi, Ankara.

Ordu Buyuksehir Belediyesi Stratejik Plani, 2015-2019.

Oztop, S. (2007). “Stratejik Planlamanin Belediyelerde Uygulanmasi”, Kocaeli Universitesi, Sosyal Bilimler Enstitusu, Siyaset Bilimi ve Kamu Yonetimi Anabilim Dali, Yayımlanmis Yuksek Lisans Tezi.

Parlak, B., \& Sobaci, Z. (2010). Kuram ve Uygulamada Kamu Yonetimi Ulusal ve Kuresel Perspektifler, 3.Baski, Alfa Aktuel Yay., Bursa.

Pearce II, J. A. (1982). “The Company Mission as a Strategic Tool”, Sloan Management Review, $23,74-85$.

Pearce II, J. \& David, F. (1987). “Corporate Mission Statements: the Bottom Line”, Academy of Management Exec. (1), 109-114.

Powers, E. L. (2012). “Organizational Mission Statement Guidelines Revisited”, International Journal of Management \& Information Systems. 16, 281-290.

Sakarya Buyuksehir Belediyesi Stratejik Plani, 2015-2019.

Samsun Buyuksehir Belediyesi Stratejik Plani, 2015-2019.

Sanliurfa Buyuksehir Belediyesi Stratejik Plani, 2015-2019.

Tekirdag Buyuksehir Belediyesi Stratejik Plani, 2015-2019.

Trabzon Buyuksehir Belediyesi Stratejik Plani, 2015-2019.

Tumer, S. (1993). “Neden Stratejik Yonetim”, Verimlilik Dergisi, Sayi: 1, 1993/1, Ankara.

Yuksel, F. (2002), ”Surekli Degisen Kentsel Faktorler Karsisinda Yerel Yonetimlerde Stratejik Planlama Geregi”, Cagdas Yerel Yonetimler Dergisi, TODAIE, Cilt 11, Sayi 1, Ocak 2002, Ankara, s.31-41. 